Acta vet. scand. $1969,10,225-233$.

From the Department of Microbiology and Immunology, Veterinary College of Norway, Oslo.

\title{
ENZYMO-SEROLOGICAL COMPARISON OF PROTEOLYTIC ENZYMES PRODUCED BY SALMONELLA SPECIES AND OTHER ENTEROBACTERIA
}

\author{
By \\ Olav Sandvik ${ }^{\star}$ )
}

In recent years efforts have been made to increase the significance of certain biochemical tests in microbial taxonomy. In addition to a simple testing of biocatalytic properties, so-called enzymo-serological examinations have been performed, in order to obtain a further classification of the enzymes responsible for the biochemical abilities of the organism (Liu 1962, Sandvik 1962, Smit \& Coetzee 1967). The theory behind this procedure is that the observation of 2 organisms being able to decompose or synthesize the same compound should not be considered a criterion of close taxonomic relationship, unless the biochemical activity is due to serologically identical, or closely related, enzymes. By combining the tests for certain biochemical activities with enzymo-serological analyses of the enzymes catalyzing those activities, it should thus be possible to identify selected antigens that are labelled by their biocatalytic properties.

In the family Enterobacteriaceae, enzymo-serological studies have been carried out with proteinases (Sandvik) and phenylalanine deaminases (Smit \& Coetzee). The procedure described by Sandvik for the serological differentiation of microbial protein-

*) The author is greatly indebted to Centre International des Salmonella, Institut Pasteur, Paris for providing type cultures of Salmonella. 
ases is an immuno-electrophoretic method. By this technique, the specific proteinase anti-enzymes are separated by paper electrophoresis from the normal interfering proteinase inhibitors in the sera of immunized rabbits. The anti-proteolytic effect of the specific antibodies is demonstrated by their ability to inhibit the corresponding enzymes from precipitating sodium caseinate in an agar medium. Most enzymes studied by this procedure are specific for species, and cross-reactions between species and genera have only been observed in cases where a more or less close relationship cannot be excluded between the organisms in question. Thus, the antigenicity of these enzymes seems to be of considerable taxonomic significance.

As the antigens used in this method are labelled by their functional properties, they may be serologically identified without purification.

Enzymo-serological studies of proteolytic enzymes within the genus Salmonella have only been published for S. schleissheim, which produces proteinases serologically distinct from the corresponding enzymes of the genera Proteus, Serratia and Aerobacter $\left.^{\star}\right)$ (Sandvik).

The present paper deals with enzymo-serological examinations of proteolytic species of the Salmonella sub-genera (Kauffmann 1966) I (atypical), II and IV. The object of the examinations has been both to compare the Salmonella species with each other, and to point out their possible enzymo-serological relationship to other genera of the family Enterobacteriaceae.

\section{MATERIALS AND METHODS}

Strains. A total of 11 Salmonella strains used in this study were obtained from different culture collections (Table 1). Five strains of other genera of the family Enterobacteriaceae and the family Pseudomonadaceae were included for comparison.

Enzymes. The various proteinases were produced by growing the organisms on semi-solid skim milk agar (nutrient broth, $40 \%$; nutrient agar, $42 \%$; autoclaved skim milk, $18 \%$ ) in Roux bottles or on sterile skim milk, without agar, in $10 \mathrm{ml}$ amounts in screw-cap bottles. These cultures were incubated at $37^{\circ} \mathrm{C}$ for 2--28 days. To some extent, proteinases were also produced by

*) Enterobacter (Kauffmann 1966). 
growing strains on nutrient gelatin at room temperature for up to 90 days. Generally, the time of incubation was determined for each culture according to the concentration of enzyme accumulated. The titration of enzymes, harvesting of cultures and concentration and purification procedures have been described (Sandvik 1962).

Sera. Specific anti-proteinases were produced in rabbits. The crude concentrated enzyme preparations were mixed with equal amounts of Freund's complete adjuvant (Difco) (other lipid adjuvants have also been used successfully) and injected subcutaneously in amounts of $2.0-4.0 \mathrm{ml}$ at 6-days' intervals. Eight days after the third injection the blood sera were tested for specific antibodies against the proteinases. Sera were prepared against (a) S. schleissheim, (b) S. texas and (c) S. makoma (Table 1). Previously prepared anti-sera against Proteus vulgaris, Aerobacter cloacae, Serratia marcescens, Pseudomonas aeruginosa and Aeromonas liquefaciens were also included for comparison.

Caseinate medium. The indicator medium used to test for proteinase activity was prepared as follows:

Agar (Difco, Bacto-agar 0140-01), $1.40 \%$; sodium caseinate ${ }^{\star}$ ) (added as a $4.0 \%$ solution of $\mathrm{pH} 6.4$ ), $1.00 \%$; thimerosal, $0.01 \% ; \mathrm{MgCl}_{2}$ (added as a $10.0 \%$ solution), $0.004 \mathrm{M}$; in distilled water. After pouring, the medium remains transparent even after incubation at $37^{\circ} \mathrm{C}$, while the so-called CP-type of proteolytic enzymes causes distinct greyish-white precipitation zones in the medium after incubation (Sandvik).

Serological differentiation. The immuno-electrophoretic procedure for the separation of the specific anti-proteinases and the normal proteinase inhibitors in the serum, has been described (Sandvik). By this procedure, the normal inhibitors are localized in the $\alpha$ - and $\beta$-globulins on the anode side of the line of application, while the inhibition due to specific antibodies occurs in the area of the $\gamma$-globulins (Fig. 1).

Under the present conditions, the $\gamma$-globulins are situated on both sides of the line of application. The width of the specific inhibition zone will depend on the concentration of enzyme antibodies in the $\gamma$-globulins, and on the strength of the enzyme used for developing the elcetrophoretic patterns.

*) P 914, Eastman Kodak, Rochester, N. Y., U. S. A. 


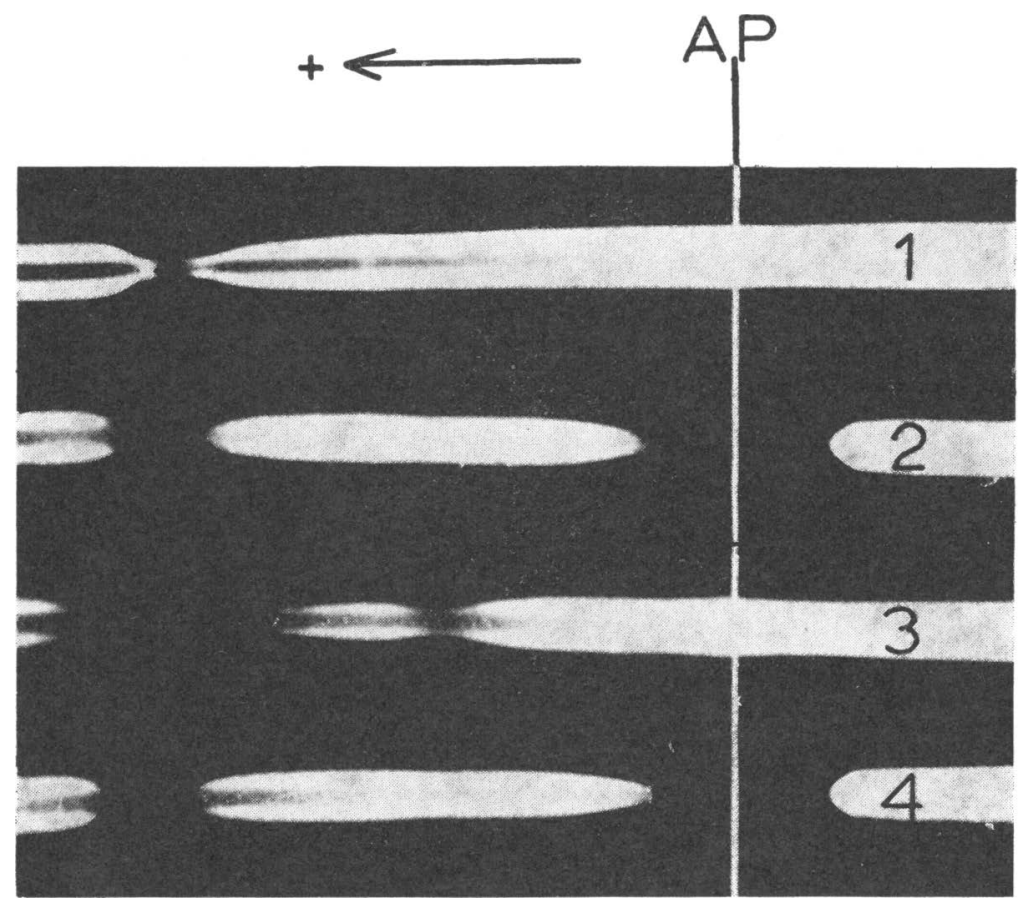

Figure 1. Electrophoretic patterns for anti-serum against casein precipitating enzymes from Salmonella schleissheim, transferred to sodium caseinate agar. Developments are performed with enzymes produced by S. texas (1), S. schleissheim (2), S. makoma (3) and S. abortus-bovis (4). The specific antibodies are localized in an area on both sides of the line of application (AP) and the normal serum inhibitors to the left of this line. Specific inhibition of the precipitation has taken place for 2 and 4 .

The electrophoresis was carried out in $0.05 \mathrm{M}$ phosphate buffer at $\mathrm{pH} 6.2$ for $18 \mathrm{hrs}$. at $120 \mathrm{v}$.

\section{RESULTS}

The Salmonella species S. schleissheim, S. abortus-bovis and S. texas were effective producers of extracellular proteinases which caused characteristic precipitation zones when applied onto the caseinate medium. All the other Salmonella strains included in Table 1 were poor proteinase producers, although sufficient yields were obtained after incubating skim milk cultures up to 28 days. The enzymes of these strains caused a fainter and greyer precipitation in the caseinate medium than the proteinases of the above-mentioned effective enzyme producers. All the 
T a b l e 1. Proteinases produced by different Salmonella species and other Gramnegative organisms tested with various anti-proteinases.

\begin{tabular}{|c|c|c|c|c|c|c|c|}
\hline \multirow[b]{2}{*}{$\begin{array}{l}\text { Proteinases } \\
\text { produced by }\end{array}$} & \multirow[b]{2}{*}{$\begin{array}{l}\text { Sub- } \\
\text { ge- } \\
\text { nus }\end{array}$} & \multicolumn{6}{|c|}{ Reaction when testing the proteinases with anti-enzymes against } \\
\hline & & $\begin{array}{c}\text { Salmo- } \\
\text { nella } \\
\text { schleiss- } \\
\text { heim } \\
\text { (NVH 1003) }\end{array}$ & $\begin{array}{l}\text { Salmo- } \\
\text { nella } \\
\text { texas } \\
\text { (ATCC } \\
11999)\end{array}$ & $\begin{array}{l}\text { Salmonella } \\
\text { makoma } \\
\text { (ISC 1665) }\end{array}$ & $\begin{array}{c}\begin{array}{c}\text { Serratia } \\
\text { marces- } \\
\text { cens }\end{array} \\
(\mathrm{NCIB} \\
\mathbf{1 3 7 7})\end{array}$ & $\begin{array}{l}\text { Aerobacter } \\
\text { cloacae } \\
\text { (NIRD 612) }\end{array}$ & $\begin{array}{c}\text { Proteus } \\
\text { vulgaris } \\
\text { (NVH 418) }\end{array}$ \\
\hline $\begin{array}{l}\text { Salmonella schleiss- } \\
\text { heim (ATCC 12000) }^{1} \\
\text { Salmonella abortus- }\end{array}$ & I & +++ & 一 & - & - & - & 一 \\
\hline $\begin{array}{l}\text { bovis (ISC } 28)^{2} \\
\text { Salmonella texas }\end{array}$ & I & +++ & - & - & - & 一 & 一 \\
\hline $\begin{array}{l}\text { (ATCC 11999) } \\
\text { Salmonella uphill }\end{array}$ & I & - & +++ & 一 & + & - & - \\
\hline $\begin{array}{l}\text { (ISC 447) } \\
\text { Salmonella uphill }\end{array}$ & II & - & - & +++ & ++ & +++ & 一 \\
\hline $\begin{array}{l}(\text { NVH 560) } \\
\text { Salmonella makoma }\end{array}$ & II & - & - & +++ & ++ & ++ & - \\
\hline $\begin{array}{l}\text { (ISC 1665) } \\
\text { Salmonella caledon }\end{array}$ & II & - & - & +++ & ++ & +++ & - \\
\hline $\begin{array}{l}\text { (ISC 1448) } \\
\text { Salmonella nairobi }\end{array}$ & II & - & - & +++ & ++ & +++ & 一 \\
\hline $\begin{array}{l}\text { (ISC 353) } \\
\text { Salmonella sofia }\end{array}$ & II & - & - & +++ & ++ & +++ & - \\
\hline $\begin{array}{l}\text { (ISC 950) } \\
\text { Salmonella kluetjen- }\end{array}$ & II & - & - & +++ & ++ & +++ & - \\
\hline $\begin{array}{l}\text { felde (ISC 1702) } \\
\text { Salmonella argen- }\end{array}$ & II & - & - & +++ & $(+)$ & + & - \\
\hline tina (ISC) & IV & - & - & - & - & - & - \\
\hline $\begin{array}{l}(\text { NCIB 1371) } \\
\text { Aerobacter cloacae }\end{array}$ & & - & - & $(+)$ & +++ & - & 一 \\
\hline $\begin{array}{l}(\text { NIRD } 612)^{5} \\
\text { Proteus vulgaris }\end{array}$ & & - & - & & + & +++ & - \\
\hline $\begin{array}{l}\text { (NVH 418) } \\
\text { Aeromonas liquefaci }\end{array}$ & iens & - & - & - & - & - & +++ \\
\hline $\begin{array}{l}\text { (ATCC } 14715 \text { ) } \\
\text { Pseudomonas aerugi } \\
\text { (NVH 982) }\end{array}$ & osa & - & - & - & - & - & 一 \\
\hline
\end{tabular}

+++ : Inhibitory effect equal to homologous reaction.

$(+),+,++$ : Different degrees of reaction.

-: No reaction.

1 American Type Culture Collection, Rockville, Maryland, U.S.A.

2 Centre International des Salmonella, Institut Pasteur, Paris.

3 The culture collection of the Department of Microbiology and Immunology, Veterinary College of Norway, Oslo.

4 National Collection of Industrial Bacteria, Torry Research Station, Aberdeen, Scotland.

5 National Institute for Research in Dairying, Reading, England. 
examined strains that liquefied gelatin were also positive when tested by the casein precipitation test.

Enzymes of the included Salmonella strains and 3 additional organisms from other genera of the family Enterobacteriaceae were cross-tested with the anti-enzymes listed in Table 1. Proteinases produced by the Salmonella strains were also tested with anti-proteinases against Pseudomonas aeruginosa and Aeromonas liquefaciens. These tests were negative. Typical examples of enzymo-serological tests are shown in Fig. 1.

It may be seen from Table 1 that, within the Salmonella subgenus I, the enzymes of S. schleissheim and S. abortus-bovis were equally neutralized by the $S$. schleissheim anti-enzyme, whereas the enzymes of $S$. texas were enzymo-serologically distinctly different from these 2 species. The enzymes of the included species of sub-genus II all showed an identical, or closely related, enzymo-serological picture. The only examined representative of sub-genus IV, S. argentina, was enzymo-serologically distinct from all other organisms involved. Intergeneric cross-reactions were observed between enzymes of members of the genera Salmonella, Aerobacter and Serratia. This tendency was especially remarkable for the members of Salmonella sub-genus II. No serological relationship was observed between Salmonella proteinases and proteinases produced by strains of Proteus, Aeromonas or Pseudomonas.

\section{DISCUSSION}

The present experiments indicate that, like a variety of other gelatin liquefying organisms (Sandvik 1962), the gelatin positive Salmonella species bring about a casein precipitation reaction (CP-reaction). However, the strains of the Salmonella sub-genus II seem to be comparatively poor producers of CP-enzymes.

Within the Salmonella sub-genus I, close enzymo-serological similarity, or identity, seems to exist between the proteinases of S. schleissheim and S. abortus-bovis. These species are also closely related in the Kauffmann-White system with antigen formulae 4,12,27:b:-, and 1,4,12,27:b: e,n,x, respectively. The third species of sub-genus I, S. texas was found to be enzymoserologically distinct. All the 7 included species of sub-genus II exhibited a remarkable enzymo-serological uniformity. The observed close enzymo-serological relationship between a number of Salmonella species is not very surprising, as there is 
reason to believe that the species in question may be sufficiently related genetically to possess one, or more, identical genetic markers. However, proof of this genetic hypothesis will have to await transformation experiments and DNA analyses.

The observation that intergeneric serological cross-reactions occurred between CP-enzymes of Salmonella sub-genus II and Enterobacter (Aerobacter) cloacae and Serratia marcescens is also interesting from a taxonomic point of view. This result should be considered in relation to several reports on intergeneric transfer of genetic determinants within the family Enterobacteriaceae (Falkow et al. 1961, Marmur et al. 1961). The many examples of atypical biochemical variants within certain genera (groups) of this family (Edwards \& Ewing 1962) may also support the well-known hypothesis that the generic borders are less distinct than in many other families of micro-organisms. Thus, the biochemical difference between extreme variants of different enterobacterial genera may sometimes be minimal or absent. On this basis, the close enzymo-serological relationship between CP-enzymes of different genera is not too surprising. It is conspicuous, however, that the proteinases of Salmonella sub-genus II are closely related serologically to the tribus Klebsiellae (the genera Enterobacter and Serratia), although the former showed no such relationship to the proteolytic species of Salmonella subgenus I or the single included species of sub-genus IV.

It may be seen from Table 1 that the experiments indicate some enzymo-serological relationship between members of the 2 genera Enterobacter and Serratia. This is in accordance with earlier observations (Sandvik). As only partial cross-reaction has been observed between the 2 genera, the serological relationship may involve only 1 of 2 , or more, fractions of proteolytic enzymes. A similar mechanism is also suggested for species within the genus Aeromonas of the family Pseudomonadaceae (Sandvik \& Hagen 1968).

\section{REFERENCES}

Edwards, P. R. \& W. H. Ewing: Identification of Enterobacteriaceae. Burgess Publishing Company, Minneapolis 1962.

Falkow, S., J. Marmur, W. F. Carey, W. M. Spilman \& L. S. Baron: Episomic transfer between Salmonella typhosa and Serratia marcescens. Genetics 1961, 46, 703-706.

Kauffmann, F.: The Bacteriology of Enterobacteriaceae. Munksgaard, Copenhagen 1966. 
Liu, P. V.: Fermentation reactions of Pseudomonas caviae and its serological relationship to aeromonads. J. Bact. 1962, 83, 750753.

Marmur, J., R. Rownd, S. Falkow, L. S. Baron, C. Schildkraut \& P. Doty: The nature of intergeneric episomal infection. Proc. nat. Acad. Sci. (Wash.) 1961, 47, 972-979.

Sandvik, O.: Studies on casein precipitating enzymes of aerobic and facultatively anaerobic bacteria. The Veterinary College of Norway, Oslo 1962, 116 pp.

Sandvik, O. \& O. Hagen: Serological studies on proteinases produced by Aeromonas salmonicida and other aeromonads. Acta vet. scand. 1968, 9, 1-9.

Smit, J. A. \& J. N. Coetzee: Serological specificities of phenylalanine deaminases of the Proteus-Providence group. Nature (Lond.) 1967, 214, 1238-1239.

\section{SUMMARY}

The proteolytic enzymes produced by 11 Salmonella species of the Sub-genera I, II and IV, have been compared by a so-called enzymo-serological procedure. In sub-genus I, the enzymes of S. schleissheim and S. abortus-bovis showed an identical, or closely related, serological picture, whereas $\mathrm{S}$. texas was serologically distinct.

All the 7 examined strains of sub-genus II produced proteolytic enzymes which were serologically very similar, or identical. No enzymo-serological cross-reactions were observed between these organisms and the members of sub-genus I. The only examined species of sub-genus IV, S. argentina, was enzymo-serologically distinct from all other species.

Intergeneric cross-reactions occurred between the enzymes from Salmonella species, Enterobacter (Aerobacter) cloacae and Serratia marcescens. The significance of these cross-reactions is discussed.

\section{ZUSAMMENFASSUNG}

Ein enzym-serologischer Vergleich von proteolytischen Enzymen produziert von Salmonella-Arten und anderen Enterobakterien.

Bei einer sogenannten enzym-serologischen Methode wurde ein Vergleich von 11 Salmonella-Arten, die den Sub-Genera I, II und IV angehörten, vorgenommen. Im Sub-Genus I zeigten Enzyme von S. schleissheim und S. abortus-bovis produziert ein identisches oder ein nah verwandtes serologisches Bild, während $S$. texas serologisch gesehen wohlabgegrenzt war.

Sämtliche 7 untersuchten Stämme vom Sub-Genus II produzierten proteolytische Enzyme, die serologisch verwandt oder identisch waren. Die einzige untersuchte Art vom Sub-Genus IV, S. argentina, war enzym-serologisch distinkt verschieden von all den anderen Arten. 
Intergenerische Kreuzreaktionen wurden zwischen Enzymen produziert von Salmonella-Arten, Enterobacter (Aerobacter) cloacae und Serratia marcescens festgestellt. Die Bedeutung von diesen Kreuzreaktionen wird diskutiert.

\section{SAMMENDRAG}

Enzymo-serologisk sammenligning av proteolytiske enzymer produsert av Salmonella-arter og andre enterobakterier.

Ved en såkalt enzymo-serologisk metode har en foretatt sammenligning av 11 Salmonella-arter tilhørende sub-genera I, II og IV. Innen sub-genus I viste enzymer produsert av S. schleissheim og S. abortusbovis et identisk eller nært beslektet serologisk bilde, mens $S$. texas var velavgrenset serologisk sett.

Alle de 7 unders $\varnothing$ kte stammer av sub-genus II produserte proteolytiske enzymer som var serologisk tilsvarende eller identiske. Den eneste unders $\varnothing$ kte art av sub-genus IV, S. argentina, var enzymoserologisk distinkt forskjellig fra alle andre arter.

Intergeneriske kryssreaksjoner ble påvist mellom enzymer produsert av Salmonella-arter, Enterobacter (Aerobacter) cloacae og Serratia marcescens. Betydningen av disse kryssreaksjoner er diskutert.

(Received January 13, 1969). 